Published in final edited form as:

Expert Rev Clin Pharmacol. 2017 September ; 10(9): 935-945. doi:10.1080/17512433.2017.1356717.

\title{
Atezolizumab for the treatment of non-small cell lung cancer
}

\author{
Fernando C. Santini ${ }^{1,2}$ and Charles M. Rudin ${ }^{2}$ \\ ${ }^{1}$ Division of Medical Oncology, Instituto do Câncer do Estado de São Paulo, Hospital Sírio \\ Libanês, São Paulo, Brazil \\ ${ }^{2}$ Thoracic Oncology Service, Department of Medicine, Memorial Sloan Kettering Cancer Center, \\ New York, USA
}

\begin{abstract}
Introduction-The immune system can restrain or promote cancer development and growth. Antibodies targeting immune checkpoints have revolutionized cancer treatment. Among the best responses have been in non-small cell lung cancer (NSCLC) which is largely caused by chronic exposure to carcinogens; associated with high neoantigen creation and sensitization to immune recognition. Atezolizumab was the first approved antibody that targets the PD-1 ligand (PD-L1).
\end{abstract}

Areas Covered-This drug profile article covers the basics of the cancer-immunity cycle and reviews some aspects of innate and adaptive immunology. We discuss the discovery of PD-L1 and PD-L2 while highlight the potential differences in targeting PD-L1 versus PD-1. In addition, we briefly summarized the available pre-clinical and clinical data of atezolizumab use in NSCLC. A special section covers the challenges of PD-L1 immunohistochemistry assay.

Expert commentary-PD-1:PD-L1 blockade has taken the lead in the immunotherapeutics field and represents the backbone of developing combination immunotherapies. Atezolizumab represents a step forward in the treatment of advanced NSCLC, nonetheless PD1:PD-L1 blockade in early-stage lung cancer is still a matter of debate.

\section{Keywords}

Atezolizumab; Immunotherapy; Lung cancer; PD-L1

\section{Brief review of immunology for non-immunologists}

Exploration of how the immune system affects cancer progression extends at least back to 1893, when William Coley began treating cancer patients with a mixture of heat-killed bacteria. Shortly thereafter, in the early 1900s, Paul Ehrlich began formulating a theoretical basis for the possible protective effects of immunity against cancer.

Correspondence to: Charles M. Rudin, rudinc@mskcc.org, Memorial Sloan Kettering Cancer Center. 300 East 66th Street, New York, NY, 10065. Phone: 646888 4527, Fax: 6468884676.

Declaration of Interest

CM Rudin has been a paid consultant regarding anti-cancer drug development for Abbvie, Araxes, AstraZeneca, BMS, Celgene, G1 Therapeutics, Harpoon, and Novartis. The authors have no other relevant affiliations or financial involvement with any organization or entity with a financial interest in or financial conflict with the subject matter or materials discussed in the manuscript apart from those disclosed. 
The last twenty years have seen a dramatic reemergence of interest in this field, with an increasing body of research suggesting that one of the hallmarks of cancer is tumor evasion of immunological destruction [1,2]. Genomic instability and mutation are characteristics of malignant neoplasms; these can both trigger immunologic response and contribute to tumor escape from immune destruction. The interplay between the cytolytic immune system and ultimate cancer progression, including $\mathrm{T}$ cell recognition of cancer cells as "foreign" and conversely immunoediting by cancers to suppress recognition, is complex and dynamic, and has been described in three sequential phases: elimination, equilibrium and escape [3, 4].

\subsection{Cancer-immunity cycle}

In the first phase of elimination, the innate and adaptive immune system components may eradicate the developing tumor. Antigen presenting cells (APC) can capture and process tumor associated antigens (TAA) for presentation and cross-presentation through MHC (major histocompatibility complex) class II and I respectively, and migrate to draining lymph nodes. Inside secondary lymphoid organs, tumor-antigen-loaded activated dendritic cells can generate a protective cytolytic response, which may include the production of activated $\mathrm{CD}^{+}{ }^{+}$effector $\mathrm{T}$ cells and natural killer (NK) cells. Finally, cancer-specific activated $\mathrm{CD} 8^{+}$effector $\mathrm{T}$ cells and/or NK cells can return to tumor bed and perform cancer cell destruction. Despite the seeming specificity of this response, tumor cells can manage to escape through a myriad of different mechanisms[3].

The process of $\mathrm{T}$ cell activation, from a small pool of naive lymphocytes specific for a given tumor associated antigen, leads to replicative expansion generating a large number of effector T cells. Defined TAAs include neoantigens related to somatic mutations and gene rearrangements, and aberrant re-expression of developmentally silenced differentiation factors and so-called cancer testis antigens. The initial activation of naive T lymphocytes occurs mainly in secondary lymphoid organs. Several $\mathrm{T}$ cell surface proteins participate in the process of T cell activation, including TCR (T-cell receptor), adhesion molecules, coreceptors and co-stimulators, the latter two of which play critical roles in central tolerance and autoimmunity prevention.

The specific recognition of antigenic peptides presented by the MHC triggers TCR signaling. The co-stimulatory and co-inhibitory receptors on $\mathrm{T}$ cells direct $\mathrm{T}$ cell function and determine $\mathrm{T}$ cell fate. The best characterized central co-stimulatory pathway in $\mathrm{T}$ cell activation is represented by the engagement of CD28 with B7-1 (CD80) and B7-2 (CD86) which are expressed on activated APCs. This results in activation of downstream mitogenic signaling pathways including PI3K/AKT and RAS/MAPK, increased expression of antiapoptotic proteins (e.g. BCL- $\mathrm{X}_{\mathrm{L}}$ ), production of proliferative cytokines (e.g. IL-2), and differentiation of naive $\mathrm{T}$ cells into effector $\mathrm{T}$ cells[5].

Several other proteins structurally related to B7-1 and B7-2 or to CD28, have been identified. While some of these are immunostimulatory agonists, other have inhibitory mechanisms, functioning as immune checkpoints. Key inhibitory receptors of the CD28 family include CTLA-4 (cytotoxic T lymphocyte antigen 4) and PD-1 (programmed death $1)$. 
CTLA-4:B7 binding primarily inhibits the initial activation of T lymphocytes in secondary lymphoid organs, while PD-1:PD-L1 interactions are thought to play a larger role in peripheral tissues. As one might predict from the primary localization of the CTLA-4 pathway, blockage of this inhibitory pathway in the central lymphoid organs leaves the inhibitory PD-1:PD-L1 pathway in the tumor microenvironment intact, preventing killing of cancer cells by cytotoxic T lymphocytes (CTL) in the tumor bed.

Furthermore, the immune response to cancer evolves over many years and, in the case of progressive and metastatic cancer, ultimately fails. Myriad factors may contribute to this failure, but one key factor is that after prolonged antigenic exposure, the responses of effector T cells may gradually attenuate. This phenomenon is called $\mathrm{T}$ cell exhaustion $[6,7$, 8], and is characterized by reduced production of IFN- $\gamma$ and increased expression of multiple inhibitory receptors, notably PD-1. These observations among others ultimately led to the development of PD-1:PD-L1 pathway blockade as a therapeutic anti-cancer strategy.

\subsection{Discovery of PD-L1 and PD-L2}

PD-1 is expressed on a large proportion of tumor-infiltrating lymphocytes (TILs). It is transcriptionally induced on activated $\mathrm{T}$ cells, on other activated non-T lymphocyte subsets including B cells and NK cells, and on some myeloid cells $[9,10]$. The extracellular component of PD-1 consists of a single domain resembling an immunoglobulin variable region $(\operatorname{IgV})$, while the cytoplasmic component contains an immunoreceptor tyrosine-based inhibitory motif (ITIM) followed by an immunoreceptor tyrosine-based switch motif (ITSM), which is required intact for PD-1 function[11, 12]. PD-1 is considered to be a member of the CD28 superfamily and its structural similarity to CTLA-4 and CD28 led to the hypothesis that the ligand for PD-1 might be a member of the B7 family.

Dong and colleagues[13] in 1999 first described a third member of the B7 family, called B7H1 (PD-L1 or CD274) which does not bind to CD28, CTLA-4 or ICOS (inducible costimulator), however co-stimulation mediated by B7-H1 led to secretion of IL-10. Although PD-L1 shares only about 20\% amino-acid identity with B7-1 and B7-2 in its extracellular domain, the secondary structures of these molecules are very similar. They all belong to an emerging family within the immunoglobulin superfamily.

The expression of mRNA encoding PD-L1 is abundant in many tissues. Key oncogenic pathways such as PTEN-PI3K and MAPK pathway have been implicated in the posttranscriptional regulation of its cell surface expression[9]. IFN- $\gamma$ and type I interferons are also known potent inducers of PD-L1 expression. PD-L1 protein is often found constitutively in immune-privileged sites, including the eyes and placenta. PD-L1 expression in most tissues is dynamic, but has been reported to be constitutively expressed in activated $\mathrm{T}$ cells and B cells, dendritic cells, macrophages, NK cells, vascular endothelial cells and mesenchymal stem cells. PD-L1 has been found to be highly expressed in many human cancer types including melanoma, non-small cell lung cancer, nasopharyngeal carcinoma, urothelial carcinoma, gastric carcinoma, and renal cell carcinoma, among others. Levels of PD-L1 expression in cancer cells are also regulated by epigenetic mechanisms through microRNAs. Amplification of 9p24.1, which harbors $P D-L 1$ and $P D-L 2$ genes, increases 
gene dosage together with $J A K 2$ in nodular sclerosing Hodgkin's lymphoma and primary mediastinal large B-cell lymphoma[14].

Tumors expressing PD-L1 can render cytotoxic T lymphocytes (CTL) inactive or nonfunctional through engagement of the inhibitory receptor PD-1. The mechanisms by which PD-1 antagonizes T-cell receptor signaling are a subject of intense investigation. Engagement of PD-1 on activated effector T cells causes the recruitment of the phosphatase Shp2 and subsequent inactivation of the PI3K-AKT-mTOR and RAS-MEK-ERK pathways. Hui and colleagues[15] recently showed that the co-receptor CD28 is strongly preferred over the TCR as a target for dephosphorylation by PD-1-recruited Shp2 phosphatase. In addition, metabolic reprogramming has a major role in T-cell differentiation and function, with aerobic glycolysis becoming the dominant metabolic program during activation and expansion. PD-1 may alter T-cell differentiation by restraining T cells from remodeling multiple metabolic pathways. PD-1 suppresses oxygen consumption and impairs the ability of activated $\mathrm{T}$ cells to engage in glycolysis and glutaminolysis[16].

In addition to PD-1, PD-L1 may also mediate an immunosuppressive function through interaction with B7-1. Butte et al[17] showed that B7-1 and PD-L1 interact with affinity intermediate to that of B7-1:CD28 and B7-1:CTLA-4. T cell activation and cytokine production were inhibited by the interaction of B7-1 with PD-L1, pointing to a substantial bidirectional inhibitory interaction. In addition to resistance against T-cell destruction, PDL1 cancer cells also demonstrate increased resistance to Fas-mediated apoptosis [18].

In 2001, Latchman and colleagues[19] first identified and characterized PD-L2, a second ligand for PD-1. PD-L2 has been less extensively studied and its role in modulating tumor immunity is less clear. PD-L2 expression was initially thought to be restricted to antigenpresenting cells such as macrophages and dendritic cells. Relative to PD-L1, basal expression of PD-L2 is low, but its expression can be induced on a wide variety of immune and nonimmune cells by microenvironmental stimuli including Th2 cytokines. The distribution of human $P D-L 2$ mRNA in normal tissues is more restricted than $P D-L 1$. However, some tissues - such as pancreas, lung and liver - express PD-L2 but not PD-L1 and human fetal liver expressed PD-L1 but not PD-L2[19]. PD-1 engagement by PD-L2 or PD-L1 can down-regulate TCR-CD28-stimulation of cytokine production. Consistent with its more restricted tissue distribution, PD-L2 expression across tumor types is less prevalent than PD-L1.

The relative affinity of PD-L2 to PD-1 has been estimated to be 2-6 fold higher than of PD$\mathrm{L} 1$, and its binding appears to involve less complex conformational changes. Nonetheless, the fact that PD-L2 is generally expressed at a lower level may favor PD-L1 as the primary binding ligand of PD-1, except during Th2 responses, when PD-L2 is upregulated. Experimental asthma models, where a high Th2 response is expected, have demonstrated enhanced disease severity in the absence of PD-L2 signaling[20]. The more restricted expression of PD-L2, largely to antigen-presenting cells, is consistent with a role in regulating T-cell priming and T-cell polarization. However, the main physiological function of PD-L2 is still under debate[9]. 


\subsection{PD-1 versus PD-L1 blockade}

Because the PD-1/PD-L1 axis has an important role in the maintenance of self-tolerance, therapeutic targeting of this pathway can lead to imbalances in immunologic tolerance, which manifest as immune-related adverse events. A broad range of auto-immune toxicities have been reported in patients treated with inhibitors of this pathway, and nearly all organs can be affected, including skin, GI tract, lung, kidney, heart, thyroid, and pituitary, among others. Even the immune privileged organs such as the eye and the brain can be affected. Mice deficient in PD-1 develop lupus-like proliferative arthritis and late onset glomerulonephritis[21]. In preclinical models, mice deficient in PD-L2 develop less frank autoimmunity, but rather exhibit hypersensitive Th2 responses and attenuated Th1 immunity[22].

Anti-PD-1 antibodies inhibit binding of both PD-L1 and PD-L2 to PD-1 positive activated T cells, inside the tumor bed. This strategy may be particularly appropriate for tumors that express both PD-1 ligands. The possibility that PD-1 can be saturated in the blood with an anti-PD-1 antibody before $\mathrm{T}$ cell migration into tumors represents one theoretical advantage of directly targeting PD-1 over PD-L1. However, in organs with high expression of PD-L2, direct PD-1 blockade could raise the potential of increased toxicity relative to targeting PDL1.

In contrast to inhibiting PD-1, targeting PD-L1 leaves PD-L2 uninhibited, which can also represent a double-edged sword. On the one hand, PD-L1 targeting will not inhibit PD-L2dependent immunosuppressive pathways in tumors. One the other hand, leaving the PDL2:PD-1 interaction intact may preserve a component of peripheral immune homeostasis. For organs like the lung, this was hypothesized to reduce the likelihood of developing severe inflammatory toxicity. The defined role of PD-L2 in the modulation of Th2 responses, while antitumor immunity may be most dependent on Th1 responses, represents an argument for leaving PD-L2 intact.

The engagement of PD-L1, on T cells or tumor cells, with B7-1 on APCs appears to function uniquely to inhibit T-cell responses and abrogate the anti-apoptotic signaling of PDL1 pathway respectively. Targeting PD-L1 versus PD-1 provides the additional theoretical advantage of inhibiting the binding of PD-L1 with B7-1, unleashing these anti-tumor response pathways.

\section{Generation and preclinical analyses of atezolizumab (MPDL3280A)}

The anti-PD-L1 antibody MPDL3280A (subsequently named atezolizumab) was isolated by screening a human phage display library against a recombinant extracellular domain-Fc fusion of human PD-L1[23]. A high-affinity antibody was selected from a single phage clone on a human $\mathrm{IgG} 1$ backbone $\left(K_{\mathrm{d}}\right.$ (dissociation constant) $\left.=0.4 \mathrm{nM}\right)$. Binding of atezolizumab was strictly dependent on the expression of human PD-L1. Atezolizumab was engineered for reduced $\mathrm{Fc}$ effector function via a single amino acid substitution at position 298 (Asn to Ala); this substitution impairs the binding of atezolizumab to Fc $\gamma$ receptors, and so minimizes in vivo depletion of tumor specific T cells expressing high levels of PD-L1 (and PD-1), antibody-dependent cellular cytotoxicity (ADCC). In an in vitro assay for 
ADCC, the engineered antibody was unable to mediate killing of two cell lines transfected with human PD-L1. Atezolizumab blocks the interaction of PD-L1 with both PD-1 and B7.1.

Atezolizumab binding residues were moved onto a mouse $\mathrm{Fc}$, and mouse IgG2a against murine PD-L1, PRO304397, was developed in parallel to facilitate analysis in preclinical murine studies without induction of cross-species immunogenicity [24]. Analogous to atezolizumab, PRO304397 was produced in Chinese hamster ovary cells and contains 2 mutations (D266A, N298A) in the Fc domain to prevent efficient binding to murine Fc $\gamma$ receptors. PRO304397 and atezolizumab have similar PDL1 binding affinity and blocking properties toward both mouse and human PD-L1, and atezolizumab binds to PD-L1 in monkey and human with comparable affinity between species.

Deng and colleagues[24] characterized the pharmacokinetics (PK) of atezolizumab in cynomolgus monkeys, the PK/pharmacodynamics (PD) of PRO304397 in mice, and the tissue distribution and tumor penetration of PRO304397 in two isograft tumor-bearing mouse models (MC38 - murine colorectal cancer cells; and Cloudman - murine melanoma cells which are less sensitive model to PRO304397 treatment).

The PK of atezolizumab and PRO304397 was non-linear in monkeys (from 0.5 to $5 \mathrm{mg} . \mathrm{kg}$ ${ }^{-1}$ ) and mice (between 1 and $10 \mathrm{mg} \cdot \mathrm{kg}^{-1}$ ), respectively. They are within the expected range for a typical human/humanized IgG1 in the linear range. Complete saturation of PD-L1 in blood in mice was achieved at serum concentrations of PRO304397 above $0.5 \mu \mathrm{g} . \mathrm{mL}^{-1}$. Tissue distribution and tumor penetration studies of PRO304397 in tumor-bearing mice indicated that saturation of target-mediated uptake in non-tumor tissues, and desirable exposure in tumors were achieved at higher serum concentrations. A higher dose of PRO304397 resulted in a greater penetration into tumors and a relatively longer duration of PD-L1 saturation in tumors. The bio distribution data indicated that the efficacious dose is mostly likely higher than that estimated based on simple PK/PD in blood. These data also allowed for estimation of the target clinical dose and facilitated further development of atezolizumab.

\section{Clinical efficacy}

\subsection{Early phase studies}

A Phase I, multicenter, first in human, open-label, dose escalation study[23] evaluated the safety, tolerability, and pharmacokinetics of atezolizumab administered as single agent by intravenous (IV) infusion every three weeks (q3w) to participants with locally advanced or metastatic solid malignancies or hematologic malignancies. The study (NCT01375842) was conducted in dose-escalation cohorts, followed by an expansion cohort. This phase 1 study was also modified in progress to allow for tumor-specific cohorts and biomarker enriched cohorts. Single-patient dose escalation was used for $0.01,0.03$ and $0.1 \mathrm{mg} \cdot \mathrm{kg}^{-1}$ cohorts, and a traditional $3+3$ dose-escalation scheme was used for $0.3,1,3,10$, and $20 \mathrm{mg} \mathrm{kg}^{-1}$ cohorts. Five expansion cohorts were opened, including for NSCLC, renal cell carcinoma, melanoma, for other tumor types, and for patients who had mandatory serial biopsies. Formalin-fixed, paraffin-embedded (FFPE) tissue sections were stained for PD-L1 with an 
anti-human PD-L1 rabbit monoclonal antibody (clone SP142; Ventana) on an automated staining platform. In contrast to PD-L1 staining protocols pursued in conjunction with other PD-1/PD-L1 directed antibodies, analysis of PD-L1 was performed both on tumor cells and in the tumor microenvironment (see below section on the complementary diagnostic assays).

A total of 277 patients with incurable cancers were enrolled. Mean single-dose PKs were consistent with a typical IgG1 at doses $\geq 1 \mathrm{mg} \cdot \mathrm{kg}^{-1}$, with a mean terminal serum half-life of 3 weeks. Treatment-related grade 3-4 adverse events (AE) were observed in 13\% of the patients and immune-related grade 3-4 AEs were observed in 1\%. The most common AE was fatigue, which often occurred with low-grade fever during the first cycle. No cases of grades 3-5 pneumonitis were seen.

A two-fold increase in activated proliferating $\mathrm{CD}^{+} \mathrm{T}$ cells and a trend of increasing circulating IFN- $\gamma$ were observed by the end of the first cycle. The association of response to atezolizumab treatment and tumor-infiltrating immune cell PD-L1 expression reached statistical significance $(\mathrm{p}=0.007)$, while the association with tumor cell PD-L1 expression did not. RNA isolated from a regressive lesion displayed expression patterns indicative of a generalized activation of CD8 and Th1 T-cell responses. High PD-L2 expression did not appear to be associated with atezolizumab resistance. In contrast, most progressive tumors showed a lack of PD-L1 upregulation by either tumor cells or tumor-infiltrating immune cells in on-treatment biopsies.

The maximum tolerated dose of atezolizumab was not reached, and no dose-limiting toxicities were observed. Because $15 \mathrm{mg} \cdot \mathrm{kg}^{-1} \mathrm{q} 3 \mathrm{w}$ was sufficient to maintain predefined target drug levels, the equivalent fixed dose of $1200 \mathrm{~m} \mathrm{mg} \mathrm{q3w}$ was moved forward in clinical development.

Horn and colleagues[25] presented at 2015 ASCO annual meeting the updated results of the NSCLC cohort. The dose-expansion phase of this study originally enrolled patients independent of PD-L1 status, and subsequently, patients with NSCLC were selected on the basis of PD-L1 status. 88 patients with advanced NSCLC were evaluated for efficacy. Grades 3-4 AEs were observed in $11 \%$ of the patients, and fatigue was the common. No pneumonitis cases were observed. One death was reported. High overall response rates (ORR) were observed in patients with higher PD-L1 expression (TC3 or IC3), which was an independent predictor of response.

\subsubsection{Atezolizumab + chemotherapy as first-line treatment of NSCLC—While}

cytotoxic chemotherapy is transiently immunosuppressive, chemotherapy-induced tumor cytotoxicity can also result in the release of tumor antigens and danger-associated cytokine secretion, which can trigger anti-tumor T-cell immunity[26]. Chemotherapeutic agents can modulate the activity of distinct immune cell subsets or the immune phenotype of tumor and stromal cells. These effects can include enhancing antigen presentation, enhancing expression of costimulatory molecules or downregulating checkpoint molecules. Strategically combining checkpoint inhibitors with chemotherapy can in theory potentiate the anti-tumor response. Defining the optimal choice of chemotherapy agent and timing of 
these combinations in different disease contexts will be very important as chemotherapy drugs that deplete proliferating lymphocytes may be detrimental.

Liu and colleagues[27] reported the results of the phase 1b study (NCT01633970) designed to evaluate the safety, pharmacology and preliminary efficacy of atezolizumab administered with carboplatin/paclitaxel (Arm C), carboplatin/pemetrexed (Arm D) or carboplatin/nabpaclitaxel (Arm E) as first-line treatment in patients with locally advanced or metastatic NSCLC. 30 patients receiving atezolizumab plus chemotherapy were evaluated for response. The combination demonstrated robust response rates, with ORR of $67 \%$ (95\% CI, 47\%$83 \%$ ) while complete responses seen in $10 \%$ of the patients. Median duration of response was 24 weeks in Arm C, and had not been reached at the time of reporting for other arms. Responses were seen independent of PD-L1 expression. Overall, treatment was well tolerated without apparent exacerbation of chemotherapy-associated adverse events and no pneumonitis was observed. Potential additive or synergistic effects with the combination of atezolizumab and chemotherapy are being further explored in randomized phase 3 trials.

(Table 7)

\subsection{Phase 2 studies}

The first phase 2 trial was a single-arm study[28] ("FIR") of atezolizumab, in PD-L1 selected positive patients with stage IIIB/IV NSCLC (NCT01846146), designed to evaluate the efficacy, safety and the relationship between PD-L1 status and efficacy. The primary endpoint was ORR. Eligible participants were categorized into three groups as follows: participants with no prior chemotherapy for advanced disease (cohort 1); participants who progressed during or following a prior-platinum based chemotherapy regimen for advanced disease (cohort 2); and participants who were previously treated for brain metastases and progressed during or following a prior-platinum based chemotherapy regimen for advanced disease (cohort 3). The majority of the patients were enrolled into cohort 2, as two other competing studies were ongoing - "BIRCH" and "OAK" trials. A comparison of outcomes based on modified RECIST (mRECIST) and RECIST v1.1 was also performed. The mRECIST criteria accommodate the possible appearance of new lesions and potential immune-related increases in tumor burden that can appear as progression when RECIST v1.1 is used.

Different PD-L1 selection criteria ([TC2/3 or IC2/3] and IC2/3; Table 1) were employed during the enrollment period for FIR. Overall, the observed prevalence of TC2/3 or IC2/3 tumors was 39\%. There was close agreement between mRECIST and RECIST 1.1. In cohort 2, of 93 patients, the ORR was $17 \%$ by mRECIST and $16 \%$ by RECIST 1.1 . In cohort 1 , of 31 patients, the ORR was $29 \%$ by mRECIST and $26 \%$ by RECIST 1.1 . Clinical benefit was observed in all cohorts. TC3 and IC3 were independent predictors of response in cohort 2. 95 patients had paired metachronous tumor samples for IHC comparison, which was generally consistent, suggesting that either fresh or archival tissues can be reliably used to assess PD-L1 expression. Atezolizumab showed clinical benefit and an acceptable safety profile in both chemotherapy-naïve and previously treated NSCLC, including patients with known brain metastasis. 
The subsequent "POPLAR" study[29] was designed to investigate the efficacy and safety of atezolizumab versus docetaxel in second-line and third-line NSCLC, and to further assess the predictive value of PD-L1 expression levels on tumor cell and tumor-infiltrating immune cells. This was a multicenter, international, randomized, open-label, all-comer phase 2 trial. Patients were stratified by tumor-infiltrating immune-cell PD-L1 expression, previous lines of chemotherapy, and histology. Patients received intravenous atezolizumab (1200 mg fixed dose) or docetaxel $\left(75 \mathrm{mg} / \mathrm{m}^{2}\right) \mathrm{q} 3 \mathrm{w}$ on day 1 of each 3-week cycle. The primary endpoint was overall survival in the intention-to-treat population and PD-L1 subgroups. 144 patients were randomly allocated to receive atezolizumab and 143 to receive docetaxel.

At a minimum follow-up of 13 months, atezolizumab significantly improved overall survival compared with docetaxel (12.6 vs 9.7 months; HR 0.73, 95\% CI 0.53-0.99; $\mathrm{p}=0.04$ ).

Progression-free survival was similar between groups ( 2.7 months with atezolizumab vs 3.0 months with docetaxel; HR 0.94, 95\% CI 0.72-1.23). 21 (15\%) patients in the atezolizumab group and $21(15 \%)$ patients in the docetaxel group achieved an objective response.

Overall survival in patients with TC0 and IC0 PD-L1 status in the atezolizumab group was similar to that in docetaxel group. Overall survival benefit from atezolizumab increased with increasing PD-L1 expression on tumor cells, tumor infiltrating immune cells, or both (Table 2).

Each tumor cell or tumor-infiltrating immune cell level independently contributed to the improvements in overall survival in the TC $2 / 3$ or IC $2 / 3$ and TC $1 / 2 / 3$ or IC $1 / 2 / 3$ combined groups. Additionally, patients in the atezolizumab group with PD-L1 expression on tumor cells only (TC1/2/3 and IC 0 subgroup) and tumor infiltrating immune cells only (IC1/2/3 and TC0 subgroup) had improved overall survival compared with patients receiving docetaxel. Of note, atezolizumab improved overall survival in both responding and nonresponding patients compared with docetaxel, implying that some patients may benefit after RECIST-defined progression.

Overall survival was improved in the atezolizumab group with high $P D-L 1, P D-1, B 7.1$ and $P D-L 2$ gene expression. The T-effector-associated and IFN- $\gamma$-associated gene signature was associated with PD-L1 expression in tumor-infiltrating immune cells as opposed to tumor cells. Unlike overall survival, improved PFS and ORR with atezolizumab was limited to those patients with the highest level of PD-L1 expression (TC3 or IC3 subgroup). In the atezolizumab group, median overall survival for patients with squamous carcinoma was 10.1 months and for patients with adenocarcinoma was 15.5 months.

Treatment-related grades 3-4 adverse events were observed in $11 \%$ in the atezolizumab group versus 39\% in the docetaxel group. The most common atezolizumab related grade 3 adverse events were pneumonia (three patients) and increased aspartate aminotransferase (three patients). Potential immune-mediated adverse events, such as pneumonitis, colitis, and hepatitis occurred at low frequencies $(<5 \%)$ in the atezolizumab group and were generally manageable and reversible. Grade 5 adverse events in the atezolizumab group were cardiac failure (related to study treatment), pneumonia, ulcer hemorrhage, pneumothorax, pulmonary embolism, and embolism (one patient each). 
3.2.1. First line therapy in advanced NSCLC-Peters and colleagues[30, 31] have recently reported the results of the "BIRCH" study, a phase II single-arm trial of atezolizumab as first-line or subsequent therapy for locally advanced or metastatic PD-L1selected NSCLC. Patients with PD-L1 positive tumors (TC2/3 and/or IC2/3) and without brain metastasis were eligible. They were divided in three cohorts: first-line, second-line, and third-line or more. Here we focus on the results of the cohort 1 . The primary endpoint of the study was response rate based on central radiologic review, with secondary endpoints including progression-free and overall survival. A total of 139 first-line patients was included in cohort 1 . Treatment-related adverse events were generally similar to those reported in the atezolizumab studies discussed above, with most common adverse events being fatigue (18\%) and nausea (10\%). Key outcome measures are indicated in Table 3 . The median duration of response for patients in cohort 1 of this study was 9.8 months (95\% CI, 5.6-NR).

\subsection{Phase 3 studies}

The "OAK" protocol [32] was the first phase 3 study of an anti-PD-L1 immunotherapy in NSCLC. This was a randomized, open-label, international study in patients who had received one or two previous lines of chemotherapy for stage IIIB/IV NSCLC. Patients with EGFR mutations or an ALK fusion oncogene were additionally required to have received previous FDA-approved tyrosine kinase inhibitor therapy. Patients with treated asymptomatic supra-tentorial CNS metastases were eligible. Patients were stratified by PDL1 expression (IC0 vs IC1 vs IC2 vs IC3 level), number of previous chemotherapy regimens, and histology. Treatment arms were similar to the aforementioned POPLAR trial. The primary endpoint was overall survival within the intention-to-treat (ITT) population and the PD-L1 TC1/2/3 or IC1/2/3 populations.

Of the final 1225 patients randomly assigned in the total patient population, 609 patients received atezolizumab and 578 patients received docetaxel. Of note, $40 \%$ of patients receiving atezolizumab were treated beyond progression, with median treatment duration beyond progression of three cycles. Overall survival was better with atezolizumab relative to docetaxel in both the ITT and TC1/2/3 or IC1/2/3 populations (Table 4). Overall survival was improved in the ITT population with atezolizumab (median 13.8 months) versus docetaxel (median 9.6 months), HR 0.73 (95\% CI 0.62-0.87; p=0.0003). PFS was similar between atezolizumab and docetaxel in the ITT population (2.8 months [95\% CI 2.6-3.0] versus 4.0 months [95\% CI 3.3-4.2]). Overall response was also similar between arms, $14 \%$ with atezolizumab and 13\% with docetaxel, with the exception of the TC3 or IC3 group, which showed a greater benefit with atezolizumab. Median duration of response in the ITT population was notably longer in the atezolizumab group at 16.3 months (95\% CI 10.0-not evaluable) compared with 6.2 months (4.9-7.6) in the docetaxel group.

Patients with high PD-L1 expression derived the greatest benefit from atezolizumab, although overall survival was improved regardless of PD-L1 expression levels, even in patients with $P D-L 1$ gene expression lower than the median.

Grade 3 or 4 adverse events were reported in $37 \%$ of patients treated with atezolizumab and $54 \%$ of patients treated with docetaxel. Fatigue, nausea, decreased appetite, and asthenia 
were the most common atezolizumab-related adverse events of any grade. Immune-related adverse events included pneumonitis $(2 \%)$, hepatitis, and colitis $(<1 \%)$. There were no deaths related to atezolizumab.

\section{Complementary diagnostic assay}

PD-L1 analysis has been a source of substantial research attention and controversy in clinical development of checkpoint immunotherapies. Roche/Ventana[33] have developed a complementary diagnostic for atezolizumab using an immunohistochemistry (IHC) assay and an anti-human PD-L1 rabbit monoclonal antibody (SP142) optimized to detect PD-L1 expression in both tumor cells (TC) and tumor-infiltrating immune cells (IC). The Ventana PD-L1 (SP142) assay was validated for use in FFPE samples of NSCLC in a series of studies addressing sensitivity, specificity, robustness, and precision. In a cohort of $>200$ NSCLC samples, concordance between two pathologists was > 90\%.

Tumor cells typically show membranous staining with a variably component of cytoplasmic staining. PD-L1-positive tumor-infiltrating ICs were typically seen within some patterns including aggregates towards the periphery of the tumor mass, in stromal bands dissecting the tumor mass, or as single cells scattered in the stroma. PD-L1 scores in patients with multiple specimens were based on the highest score. Specimens were scored as in Tables 1 and 5 .

\subsection{Challenges in detecting PD-L1 by immunohistochemistry}

In an ongoing effort initiated by the American Association for Cancer Research (AACR) and the International Association for the Study of Lung Cancer (IASLC) together with four pharmaceutical companies (Bristol-Meyers Squibb, Merck, Genentech/Roche, and AstraZeneca) and two diagnostic companies (Dako and Ventana), four PD-L1 assays were compared on the same set of tumors - the Blueprint Project[34] - to better understand the similarities and differences between antibodies and platforms. Each IHC assay was developed with a unique primary antibody (clone) against PD-L1, namely, 28-8 (Dako) with nivolumab, 22C3 (Dako) with pembrolizumab, SP263 (Ventana) with durvalumab, and SP142 (Ventana) with atezolizumab.

One concern in comparing PD-L1 antibodies that have been used for IHC analysis is that different antibodies bind to different extracellular and cytoplasmic domains on the PD-L1 protein. The antibodies SP142 and E1L3N bind to the cytoplasmic domain of PD-L1, while other antibodies, including 28-8, 22C3, SP263, and E1J2J all bind to the extracellular domain of the PD-L1. There is a wide difference in the PD-L1 expression measured by the different antibodies. Only the SP142 assay includes a measure of infiltrating PD-L1 positive ICs. Three pathologists, all of whom were experts in interpreting their respective clinical cutoffs of the assays used in this study, independently evaluated all 156 immuno-stained slides from the 39 cases. This analysis revealed that three PD-L1 IHC assays (28-8, 22C3, and SP263) are closely aligned with regard to PD-L1 expression on TCs, whereas SP142 consistently reported fewer TCs expressing PD-L1. All the assays demonstrated PD-L1 expression on ICs, with greater variance than expression on TCs. 
Rimm and colleagues[35] further conducted a United-States based study to again compare the performance of available antibodies, assays, and test platforms for the ability to accurately and reliably measure PD-L1 (SP142, 22C3, 28-8, and E1L3N [laboratory-based test]). This study corroborated the results from the aforementioned Blueprint pilot project, demonstrating that the SP142 assay is an outlier and that pathologists are much more consistent at scoring TCs than ICs.

\section{Overview of the market and regulatory affairs}

Based on the safety and efficacy data of the OAK and POPLAR trials, in October 2016, the FDA approved atezolizumab for the treatment of patients with metastatic NSCLC whose disease progressed during or following platinum-containing chemotherapy. Patients with $E G F R$-mutant or $A L K$-rearranged tumors should have disease progression on FDAapproved tyrosine kinase inhibitors prior to receiving atezolizumab. The SP142 assay had been previously approved in May 2016, as a complementary diagnostic test for patients with metastatic urothelial carcinoma.

Multiple other agents have been approved or are in active clinical development in this space. Pembrolizumab was the first anti-PD1 therapy to be approved for patients with recurrent metastatic NSCLC, in patients with TCs expression of PD-L1 greater than or equal $1 \%$ as determined by an FDA-approved test. Very shortly thereafter, nivolumab was approved for the same indication, without a limitation based on PD-L1 staining. Nivolumab was developed using a slightly more frequent schedule of infusion, every two weeks, versus the three week intervals for atezolizumab and pembrolizumab. In October 2016, the FDA also approved pembrolizumab for the treatment of patients with metastatic NSCLC whose tumors have PD-L1 expression greater than 50\%, with no EGFR or $A L K$ alterations, and no prior systemic treatment. Phase III trials that supported these approvals are summarized in Table 6.

\section{Expert commentary and 5-year review}

Cancer immunotherapies targeting PD-1 and PD-L1 have revolutionized the treatment of advanced non-small cell lung cancer. The ultimate goal of immunotherapy is to establish a renewable population of highly active tumor-specific $\mathrm{T}$ cells that can lyse tumor cells and durably eradicate cancers. Many efforts have been made to define biomarkers to predict the groups of patients that will respond to immunotherapy. Efficacy has been correlated with several factors including the molecular smoking signature, total mutational burden, high neoantigen load, and DNA repair pathway mutations[36, 37, 38, 39]. Pre-existing anti-tumor $\mathrm{CD} 8^{+} \mathrm{T}$-cells is of utmost importance for therapeutic PD-1/PD-L1 blockade and several groups are studying the value of immune genetic signatures[40, 41].

PD-L1 expression is heterogeneous, dynamic, and can be assessed using a multitude of assays with different characteristics[42]. The lack of consistent homogeneity between assays represents a major limitation for routine clinical use. Nevertheless, PD-L1 expression in tumor remains a key biomarker, correlating with the efficacy of anti-PD-1 and anti-PD-L1 therapies across multiple disease types.

Expert Rev Clin Pharmacol. Author manuscript; available in PMC 2018 August 13. 
Atezolizumab has improved survival irrespective of PD-L1 status and histology in the treatment of patients with advanced and recurrent NSCLC. An initial concern for possibly reduced anti-tumor efficacy due to lack of PD-L2 blockade was not confirmed.

Atezolizumab has demonstrated similar benefit, and a similar toxicity spectrum, to the FDAapproved anti-PD-1 therapies. With the limitations, inherent in PD-L1 assessment methodologies, phase II and III trials of atezolizumab have suggested that expression of PD$\mathrm{L} 1$ on tumor cell and immune cells have non-redundant roles in regulation of anti-tumor immunity and in predicting response to therapy.

One unexpected and somewhat intriguing difference that has been observed between PD-1 and PD-L1 blockade is that female patients demonstrated better outcome than male patients in the subgroup analysis of the phase III atezolizumab trial. This observation is opposite to that of the three previously published anti-PD1 phase 3 trials for recurrent advanced NSCLC, which consistently favored male patients in their subgroup analysis. We acknowledge that these trials had insufficient statistical power to make this comparison, that sex differences were not anticipated or prespecified, and as a result, future studies would need to be conducted to further address this apparent difference. A large body of data has suggested that sex is an important variable in tumor immunopathogenesis and immunotherapy response[43, 44, 45].

For NSCLC patients, whose tumors harbors specific alterations in oncogenic drivers, such as EGFR mutation, $A L K$ and $R O S 1$ rearrangement, targeted therapies have offered impressive anti-tumor activity. Unfortunately, resistance almost inevitably develops. In NSCLC mouse models and cell lines harboring EML4-ALK rearrangements and EGFR mutations, induction of PD-L1 expression due to constitutive oncogenic signaling has been reported[46, 47, 48]. Furthermore, treatment with ALK and EGFR TKIs has been shown to attenuate PDL1 expression in these models.

However, subsequent clinical reports have found that the frequency of PD-L1 expression among EGFR-mutant patients was low relative to other lung cancer patients, both prior to TKI exposure and at the time of acquired resistance. Also, few EGFR mutant and ALKpositive specimens exhibited both $\mathrm{CD} 8^{+}$tumor infiltrating lymphocytes and concomitant PD-L1 expression. Gainor and colleagues[49] observed a low objective response rate in a cohort of 58 patients treated with PD-1/PD-L1 inhibitor (3.6\% in EGFR-mutant or $A L K$ positive patients versus $23.3 \%$ in $E G F R$ wild-type and $A L K$-negative/unknown patients; $\mathrm{p}=0.053$ ). Recent meta-analyses[50] to assess the role of immune checkpoint inhibitors as second-line therapy in EGFR-mutant advanced NSCLC showed that immunotherapy does not improve OS over docetaxel in this population.

Prior to introduction of immunotherapeutics, the 5-year survival of metastatic NSCLC was approximately $1 \%$. Reports of long-term efficacy and safety with immune checkpoint inhibitors are limited. Brahmer and colleagues[51] at the 2017 AACR Conference presented updated data on the longest survival follow-up for an immune checkpoint inhibitor in advanced NSCLC, from the original phase I nivolumab dose-escalation and cohort expansion trial (CA209-009; NCT00730639). The 5-year OS in all NSCLC patients $(\mathrm{n}=129)$ was $16 \%$. OS rates were similar between histologies and, of the 16 patients who survived, 3 
had PD-L1 expression $<1 \%$ and 2 patients had stable disease and progressive disease as the best overall response. These limited but intriguing results support the potential durability of the immune response, while also underscoring the heterogeneous features of the long-term survivors.

Ongoing research efforts are focused on both better identifying the subset of long-term responders, and attempting to stimulate non-responders to achieve optimal therapeutic benefit. Understanding of the mechanisms of primary and acquired resistance to immune checkpoint inhibitors will help define the future of combination therapies[52, 53, 54]. The evasion of immune attack by cancers is clearly multifactorial, with contributing factors including a lack of strong cancer antigens or epitopes recognized by $\mathrm{T}$ cells, minimal activation of tumor-specific $\mathrm{T}$ cells, immunosuppressive tumor microenvironment, and other factors[55].

A personalized immunotherapy program may prove to be a keystone of cancer therapy. Components of such a strategy that have been and are actively being explored include pretreatment assessment of several factors including the presence of immune-related biomarkers, PD-L1 expression, quantitative and qualitative assessments of mutation burden, and location and signature of the immune infiltrate. The individual cancer-immune biology may ultimately help tailor the best strategy for each patient.

There are hundreds of ongoing immunotherapy trials, and a subset of those involving atezolizumab is presented in Table 7. Combination of checkpoint inhibitors with chemotherapy and radiation is been tried in order to augment the response rate, and ultimately lead to an improve in overall survival. Numerous additional immunomodulatory pathways as well as inhibitory factors expressed or secreted by myeloid and stromal cells in the tumor microenvironment are potential targets for synergizing with immune checkpoint blockade.

Dual anti-CTLA-4 and anti-PD-1/PD-L1 blockade is the combination that has perhaps been most extensively studied. The rationale for combining these drugs is strong, because these pathways have different mechanisms for inhibiting the function of $\mathrm{T}$ cells. Besides removing the competition for the second signal which is required for $\mathrm{T}$ cell priming and activation, CTLA- 4 blockade reduces the interaction of $\mathrm{CD}^{+} \mathrm{T}$ cells with $\mathrm{T}$ regulatory cells. This approach has demonstrated some unprecedented high response rates, but with a concomitant increase in the frequency and severity of adverse events. As one example, Hellmann and colleagues reported the first results of the "CheckMate 012"[56], an open-label phase 1 study for nivolumab (anti-PD-1) and ipilimumab (anti-CTLA-4) as first-line treatment of advanced NSCLC. In the cohort of nivolumab $3 \mathrm{mg} \cdot \mathrm{kg}^{-1} \mathrm{q} 2 \mathrm{w}$ and ipilimumab $1 \mathrm{mg} . \mathrm{kg}^{-1}$ q6w the confirmed ORR was 39\% for all-comers and $86 \%$ for patients with PD-L1 expression greater than 50\%. Grades 3-4 treatment-related adverse events were observed in $33 \%$ of the patients.

Given the breath of the emerging immunotherapy field, clinicians should be aware of the unique set of drug-related adverse effects, now known as immune-related adverse events (irAE). Fortunately, most cases can be controlled with drug discontinuation and a stepwise 
immunosuppressive approach. Rapid identification of irAEs and prompt initiation of immunosuppression may optimize outcomes $[57,58,59,60]$. Whereas most irAEs are reversible, endocrinopathies require chronic hormone replacement. Furthermore, the safety of immune checkpoint blockade in patients with underlying autoimmune disorders and interstitial chronic lung disease is unknown, since these patients have been excluded from the clinical trials.

\section{Conclusion}

The landscape of second-line treatment of patients with NSCLC has three checkpoint inhibitor drugs approved, with similar activities and safety profiles. Only atezolizumab and nivolumab are approved for patients whose tumors have PD-L1 expression $<1 \%$, which comprises $30-40 \%$ of all NSCLC patients. A head-to-head prospectively comparison between them is unlikely. Immune-related adverse events management requires a close collaboration between oncologists and other specialists, including rheumatologists and endocrinologists. Use of atezolizumab for treatment of chemotherapy naïve Stage IV NSCLC and early-stage NSCLC is being studied. This agent represents a substantial step forward in the treatment of lung cancer patients.

\section{Key issues}

- Currently approved immunotherapy agents for second line treatment for recurrent metastatic NSCLC without known actionable mutation, irrespective of PD-L1 status, include atezolizumab and nivolumab. Pembrolizumab requires tumor-cells PD-L1 expression $\geq 1 \%$.

- Atezolizumab is a humanized IgG1 antibody anti-PD-L1, modified to limit ADCC, that blocks the interaction of PD-L1 with PD-1 and B7-1.

- Atezolizumab's lack of activity against PD-L2 does not appear to have a major impact on either its activity or safety, relative to those of the PD-1 inhibitors.

- Atezolizumab has improved overall survival over docetaxel, in patients with metastatic NSCLC whose tumor progressed after platinum-based therapy.

- Checkpoint inhibitor therapy in the adjuvant or neo-adjuvant setting is still a focus of ongoing research.

- $\quad$ More investigations are needed to define optimal predictive biomarkers.

- Personalized immunotherapy is a promising tool for cancer therapy.

\section{Acknowledgments}

Funding

CM Rudin is supported by the Memorial Sloan Kettering Cancer Center Support Grant from the National Cancer Institute, P30 CA008748. 


\section{References}

Papers of special note have been highlighted as:

$*$ of interest

** of considerable interest

1. Hanahan D, Weinberg RA. The hallmarks of cancer. Cell. 2000; 100:57-70. [PubMed: 10647931]

2. Hanahan D, Weinberg RA. Hallmarks of cancer: the next generation. Cell. 2011; 144:646-74. [PubMed: 21376230]

3. Chen DS, Mellman I. Oncology meets immunology: the cancer-immunity cycle. Immunity. 2013; 39:1-10. [PubMed: 23890059]

4. Chen DS, Mellman I. Elements of cancer immunity and the cancer-immune set point. Nature. 2017; 541:321-30. [PubMed: 28102259]

5. Alegre ML, Frauwirth KA, Thompson CB. T-cell regulation by CD28 and CTLA-4. Nat Rev Immunol. 2001; 1:220-8. [PubMed: 11905831]

6. Amezquita RA, Kaech SM. Immunology: The chronicles of T-cell exhaustion. Nature. 2017; 543:190-1. [PubMed: 28225757]

7. Pauken KE, Sammons MA, Odorizzi PM, Manne S, Godec J, Khan O, Drake AM, Chen Z, Sen DR, Kurachi M, Barnitz RA, Bartman C, Bengsch B, Huang AC, Schenkel JM, Vahedi G, Haining WN, Berger SL, Wherry EJ. Epigenetic stability of exhausted T cells limits durability of reinvigoration by PD-1 blockade. Science. 2016; 354:1160-5. [PubMed: 27789795]

8. Sen DR, Kaminski J, Barnitz RA, Kurachi M, Gerdemann U, Yates KB, Tsao HW, Godec J, LaFleur MW, Brown FD, Tonnerre P, Chung RT, Tully DC, Allen TM, Frahm N, Lauer GM, Wherry EJ, Yosef N, Haining WN. The epigenetic landscape of T cell exhaustion. Science. 2016; 354:1165-9. [PubMed: 27789799]

9**. Chen DS, Irving BA, Hodi FS. Molecular pathways: next-generation immunotherapy-inhibiting programmed death-ligand 1 and programmed death-1. Clin Cancer Res. 2012; 18:6580-7. Comprehensive review of PD-1:PD-L1 axis. [PubMed: 23087408]

10. Pardoll DM. The blockade of immune checkpoints in cancer immunotherapy. Nat Rev Cancer. 2012; 12:252-64. [PubMed: 22437870]

11. Freeman GJ, Long AJ, Iwai Y, Bourque K, Chernova T, Nishimura H, Fitz LJ, Malenkovich N, Okazaki T, Byrne MC, Horton HF, Fouser L, Carter L, Ling V, Bowman MR, Carreno BM, Collins M, Wood CR, Honjo T. Engagement of the PD-1 immunoinhibitory receptor by a novel B7 family member leads to negative regulation of lymphocyte activation. J Exp Med. 2000; 192:1027-34. [PubMed: 11015443]

12. Riley JL. PD-1 signaling in primary T cells. Immunol Rev. 2009; 229:114-25. Epub 2009/05/12. [PubMed: 19426218]

13. Dong H, Zhu G, Tamada K, Chen L. B7-H1, a third member of the B7 family, co-stimulates T-cell proliferation and interleukin-10 secretion. Nat Med. 1999; 5:1365-9. [PubMed: 10581077]

14. Green MR, Monti S, Rodig SJ, Juszczynski P, Currie T, O’Donnell E, Chapuy B, Takeyama K, Neuberg D, Golub TR, Kutok JL, Shipp MA. Integrative analysis reveals selective 9p24.1 amplification, increased PD-1 ligand expression, and further induction via JAK2 in nodular sclerosing Hodgkin lymphoma and primary mediastinal large B-cell lymphoma. Blood. 2010; 116:3268-77. [PubMed: 20628145]

15. Hui E, Cheung J, Zhu J, Su X, Taylor MJ, Wallweber HA, Sasmal DK, Huang J, Kim JM, Mellman I, Vale RD. T cell costimulatory receptor CD28 is a primary target for PD-1-mediated inhibition. Science. 2017; 355:1428-33. [PubMed: 28280247]

16**. Boussiotis VA. Molecular and Biochemical Aspects of the PD-1 Checkpoint Pathway. N Engl J Med. 2016; 375:1767-78. Brief overview of the PD-1 molecular biology. [PubMed: 27806234]

17. Butte MJ, Keir ME, Phamduy TB, Sharpe AH, Freeman GJ. Programmed death-1 ligand 1 interacts specifically with the B7-1 costimulatory molecule to inhibit T cell responses. Immunity. 2007; 27:111-22. [PubMed: 17629517] 
18. Azuma T, Yao S, Zhu G, Flies AS, Flies SJ, Chen L. B7-H1 is a ubiquitous antiapoptotic receptor on cancer cells. Blood. 2008; 111:3635-43. [PubMed: 18223165]

19. Latchman Y, Wood CR, Chernova T, Chaudhary D, Borde M, Chernova I, Iwai Y, Long AJ, Brown JA, Nunes R, Greenfield EA, Bourque K, Boussiotis VA, Carter LL, Carreno BM, Malenkovich N, Nishimura H, Okazaki T, Honjo T, Sharpe AH, Freeman GJ. PD-L2 is a second ligand for PD-1 and inhibits T cell activation. Nat Immunol. 2001; 2:261-8. [PubMed: 11224527]

20. Rozali EN, Hato SV, Robinson BW, Lake RA, Lesterhuis WJ. Programmed death ligand 2 in cancer-induced immune suppression. Clin Dev Immunol. 2012; 2012:656340. [PubMed: 22611421]

21. Nishimura H, Nose M, Hiai H, Minato N, Honjo T. Development of lupus-like autoimmune diseases by disruption of the PD-1 gene encoding an ITIM motif-carrying immunoreceptor. Immunity. 1999; 11:141-51. [PubMed: 10485649]

22. Akbari O, Stock P, Singh AK, Lombardi V, Lee WL, Freeman GJ, Sharpe AH, Umetsu DT, Dekruyff RH. PD-L1 and PD-L2 modulate airway inflammation and iNKT-cell-dependent airway hyperreactivity in opposing directions. Mucosal Immunol. 2010; 3:81-91. [PubMed: 19741598]

23**. Herbst RS, Soria JC, Kowanetz M, Fine GD, Hamid O, Gordon MS, Sosman JA, McDermott DF, Powderly JD, Gettinger SN, Kohrt HE, Horn L, Lawrence DP, Rost S, Leabman M, Xiao Y, Mokatrin A, Koeppen H, Hegde PS, Mellman I, Chen DS, Hodi FS. Predictive correlates of response to the anti-PD-L1 antibody MPDL3280A in cancer patients. Nature. 2014; 515:563-7. This study evaluated several biomarkers of PD-L1 inhibition using atezolizumab. [PubMed: 25428504]

24. Deng R, Bumbaca D, Pastuskovas CV, Boswell CA, West D, Cowan KJ, Chiu H, McBride J, Johnson C, Xin Y, Koeppen H, Leabman M, Iyer S. Preclinical pharmacokinetics, pharmacodynamics, tissue distribution, and tumor penetration of anti-PD-L1 monoclonal antibody, an immune checkpoint inhibitor. MAbs. 2016; 8:593-603. [PubMed: 26918260]

25. Horn L. Clinical activity, safety and predictive biomarkers of the engineered antibody MPDL3280A (anti-PDL1) in non-small cell lung cancer (NSCLC): update from a phase Ia study. J Clin Oncol. 2015; 33(suppl) abstr 8029.

26. Emens LA, Middleton G. The interplay of immunotherapy and chemotherapy: harnessing potential synergies. Cancer Immunol Res. 2015; 3:436-43. [PubMed: 25941355]

27. Liu SV. Safety and efficacy of MPDL3280A (anti-PDL1) in combination with platinum-based doublet chemotherapy in patients with advanced non-small cell lung cancer (NSCLC). J Clin Oncol. 2015; 33(suppl) abstr 8030.

28. Spigel DR. Clinical activity and safety from a phase II study (FIR) of MPDL3280A (anti-PDL1) in PD-L1-selected patients with non-small cell lung cancer (NSCLC). J Clin Oncol. 2015; 33(suppl) abst 8028 .

29*. Fehrenbacher L, Spira A, Ballinger M, Kowanetz M, Vansteenkiste J, Mazieres J, Park K, Smith D, Artal-Cortes A, Lewanski C, Braiteh F, Waterkamp D, He P, Zou W, Chen DS, Yi J, Sandler A, Rittmeyer A, Group PS. Atezolizumab versus docetaxel for patients with previously treated non-small-cell lung cancer (POPLAR): a multicentre, open-label, phase 2 randomised controlled trial. Lancet. 2016; 387:1837-46. POPLAR Phase 2 trial in chemo-refractory advanced NSCLC. [PubMed: 26970723]

30. Wakelee H, Patel JD, Heist R, Balmanoukian A, Besse B, Felip E, Carcereny Costa E, Chow LQ, Koczywas M, Garassino MC, Christoph D, Toh CK, Johnson ML, Chaft J, Kurata T, Qiu J, Kowanetz M, Coleman S, Mocci S, Sandler A, Gettinger SN, Peters S. ORAL01.04: Phase II Trial of Atezolizumab for Patients with PD-L1-Selected Advanced NSCLC (BIRCH): Updated Efficacy and Exploratory Biomarker Results: Topic: Medical Oncology. J Thorac Oncol. 2016; 11:S251S2. [PubMed: 27969443]

31. Peters S, Gettinger S, Johnson ML, Janne PA, Garassino MC, Christoph D, Toh CK, Rizvi NA, Chaft JE, Carcereny Costa E, Patel JD, Chow LQM, Koczywas M, Ho C, Fruh M, van den Heuvel M, Rothenstein J, Reck M, Paz-Ares L, Shepherd FA, Kurata T, Li Z, Qiu J, Kowanetz M, Mocci S, Shankar G, Sandler A, Felip E. Phase II Trial of Atezolizumab As First-Line or Subsequent Therapy for Patients With Programmed Death-Ligand 1-Selected Advanced Non-Small-Cell Lung Cancer (BIRCH). J Clin Oncol. 2017 JCO2016719476. Epub 2017/06/14. 
32*. Rittmeyer A, Barlesi F, Waterkamp D, Park K, Ciardiello F, von Pawel J, Gadgeel SM, Hida T, Kowalski DM, Dols MC, Cortinovis DL, Leach J, Polikoff J, Barrios C, Kabbinavar F, Frontera OA, De Marinis F, Turna H, Lee JS, Ballinger M, Kowanetz M, He P, Chen DS, Sandler A, Gandara DR, Group OAKS. Atezolizumab versus docetaxel in patients with previously treated non-small-cell lung cancer (OAK): a phase 3, open-label, multicentre randomised controlled trial. Lancet. 2017; 389:255-65. OAK Phase 3 trial in chemo-refractory advanced NSCLC. [PubMed: 27979383]

33. Boyd ZS. Development of a PD-L1 companion diagnostic IHC assay (SP142) for atezolizumab. Cancer Immunol Res. 2016; 4(1 Supplement)

34. Hirsch FR, McElhinny A, Stanforth D, Ranger-Moore J, Jansson M, Kulangara K, Richardson W, Towne P, Hanks D, Vennapusa B, Mistry A, Kalamegham R, Averbuch S, Novotny J, Rubin E, Emancipator K, McCaffery I, Williams JA, Walker J, Longshore J, Tsao MS, Kerr KM. PD-L1 Immunohistochemistry Assays for Lung Cancer: Results from Phase 1 of the Blueprint PD-L1 IHC Assay Comparison Project. J Thorac Oncol. 2017; 12:208-22. [PubMed: 27913228]

35*. Rimm DL, Han G, Taube JM, Yi ES, Bridge JA, Flieder DB, Homer R, West WW, Wu H, Roden AC, Fujimoto J, Yu H, Anders R, Kowalewski A, Rivard C, Rehman J, Batenchuk C, Burns V, Hirsch FR, Wistuba II. A Prospective, Multi-institutional, Pathologist-Based Assessment of 4 Immunohistochemistry Assays for PD-L1 Expression in Non-Small Cell Lung Cancer. JAMA Oncol. 2017 PD-L1 diagnostic assays comparison.

36. Shukuya T, Carbone DP. Predictive Markers for the Efficacy of Anti-PD-1/PD-L1 Antibodies in Lung Cancer. J Thorac Oncol. 2016; 11:976-88. [PubMed: 26944305]

37. Rizvi NA, Hellmann MD, Snyder A, Kvistborg P, Makarov V, Havel JJ, Lee W, Yuan J, Wong P, Ho TS, Miller ML, Rekhtman N, Moreira AL, Ibrahim F, Bruggeman C, Gasmi B, Zappasodi R, Maeda Y, Sander C, Garon EB, Merghoub T, Wolchok JD, Schumacher TN, Chan TA. Cancer immunology. Mutational landscape determines sensitivity to PD-1 blockade in non-small cell lung cancer. Science. 2015; 348:124-8. [PubMed: 25765070]

38. McGranahan N, Furness AJ, Rosenthal R, Ramskov S, Lyngaa R, Saini SK, Jamal-Hanjani M, Wilson GA, Birkbak NJ, Hiley CT, Watkins TB, Shafi S, Murugaesu N, Mitter R, Akarca AU, Linares J, Marafioti T, Henry JY, Van Allen EM, Miao D, Schilling B, Schadendorf D, Garraway LA, Makarov V, Rizvi NA, Snyder A, Hellmann MD, Merghoub T, Wolchok JD, Shukla SA, Wu CJ, Peggs KS, Chan TA, Hadrup SR, Quezada SA, Swanton C. Clonal neoantigens elicit T cell immunoreactivity and sensitivity to immune checkpoint blockade. Science. 2016; 351:1463-9. [PubMed: 26940869]

39. Hellmann M, Rizvi N, Wolchok JD, Chan TA. Genomic profile, smoking, and response to antiPD-1 therapy in non-small cell lung carcinoma. Mol Cell Oncol. 2016; 3:e1048929. [PubMed: 27308563]

40. Gibney GT, Weiner LM, Atkins MB. Predictive biomarkers for checkpoint inhibitor-based immunotherapy. Lancet Oncol. 2016; 17:e542-e51. [PubMed: 27924752]

41. Tumeh PC, Harview CL, Yearley JH, Shintaku IP, Taylor EJ, Robert L, Chmielowski B, Spasic M, Henry G, Ciobanu V, West AN, Carmona M, Kivork C, Seja E, Cherry G, Gutierrez AJ, Grogan TR, Mateus C, Tomasic G, Glaspy JA, Emerson RO, Robins H, Pierce RH, Elashoff DA, Robert C, Ribas A. PD-1 blockade induces responses by inhibiting adaptive immune resistance. Nature. 2014; 515:568-71. [PubMed: 25428505]

42. Rehman JA, Han G, Carvajal-Hausdorf DE, Wasserman BE, Pelekanou V, Mani NL, McLaughlin J, Schalper KA, Rimm DL. Quantitative and pathologist-read comparison of the heterogeneity of programmed death-ligand 1 (PD-L1) expression in non-small cell lung cancer. Mod Pathol. 2017; 30:340-9. [PubMed: 27834350]

43. Lin PY, Sun L, Thibodeaux SR, Ludwig SM, Vadlamudi RK, Hurez VJ, Bahar R, Kious MJ, Livi CB, Wall SR, Chen L, Zhang B, Shin T, Curiel TJ. B7-H1-dependent sex-related differences in tumor immunity and immunotherapy responses. J Immunol. 2010; 185:2747-53. [PubMed: 20686128]

44. Klein SL, Flanagan KL. Sex differences in immune responses. Nat Rev Immunol. 2016; 16:62638. [PubMed: 27546235]

45. Yang L, Huang F, Mei J, Wang X, Zhang Q, Wang H, Xi M, You Z. Posttranscriptional Control of PD-L1 Expression by 17beta-Estradiol via PI3K/Akt Signaling Pathway in ERalpha-Positive 
Cancer Cell Lines. Int J Gynecol Cancer. 2017; 27:196-205. Epub 2016/11/22. [PubMed: 27870715]

46. Ota K, Azuma K, Kawahara A, Hattori S, Iwama E, Tanizaki J, Harada T, Matsumoto K, Takayama K, Takamori S, Kage M, Hoshino T, Nakanishi Y, Okamoto I. Induction of PD-L1 Expression by the EML4-ALK Oncoprotein and Downstream Signaling Pathways in Non-Small Cell Lung Cancer. Clin Cancer Res. 2015; 21:4014-21. [PubMed: 26019170]

47. Akbay EA, Koyama S, Carretero J, Altabef A, Tchaicha JH, Christensen CL, Mikse OR, Cherniack AD, Beauchamp EM, Pugh TJ, Wilkerson MD, Fecci PE, Butaney M, Reibel JB, Soucheray M, Cohoon TJ, Janne PA, Meyerson M, Hayes DN, Shapiro GI, Shimamura T, Sholl LM, Rodig SJ, Freeman GJ, Hammerman PS, Dranoff G, Wong KK. Activation of the PD-1 pathway contributes to immune escape in EGFR-driven lung tumors. Cancer Discov. 2013; 3:1355-63. [PubMed: 24078774]

48. Azuma K, Ota K, Kawahara A, Hattori S, Iwama E, Harada T, Matsumoto K, Takayama K, Takamori S, Kage M, Hoshino T, Nakanishi Y, Okamoto I. Association of PD-L1 overexpression with activating EGFR mutations in surgically resected nonsmall-cell lung cancer. Ann Oncol. 2014; 25:1935-40. Epub 2014/07/11. [PubMed: 25009014]

49. Gainor JF, Shaw AT, Sequist LV, Fu X, Azzoli CG, Piotrowska Z, Huynh TG, Zhao L, Fulton L, Schultz KR, Howe E, Farago AF, Sullivan RJ, Stone JR, Digumarthy S, Moran T, Hata AN, Yagi Y, Yeap BY, Engelman JA, Mino-Kenudson M. EGFR Mutations and ALK Rearrangements Are Associated with Low Response Rates to PD-1 Pathway Blockade in Non-Small Cell Lung Cancer: A Retrospective Analysis. Clin Cancer Res. 2016; 22:4585-93. [PubMed: 27225694]

50. Lee CK, Man J, Lord S, Links M, Gebski V, Mok T, Yang JC. Checkpoint Inhibitors in Metastatic EGFR-Mutated Non-Small Cell Lung Cancer-A Meta-Analysis. J Thorac Oncol. 2017; 12:403-7. [PubMed: 27765535]

51. Brahmer J. Proceedings of the American Association for Cancer Research. Vol. 58. Washington, DC; 2017 Apr. Five-year follow-up from the CA209-003 study of nivolumab in previously treated advanced non-small cell lung cancer (NSCLC): Clinical characteristics of long-term survivors; 15.

52. Mahoney KM, Rennert PD, Freeman GJ. Combination cancer immunotherapy and new immunomodulatory targets. Nat Rev Drug Discov. 2015; 14:561-84. [PubMed: 26228759]

53. Smyth MJ, Ngiow SF, Ribas A, Teng MW. Combination cancer immunotherapies tailored to the tumour microenvironment. Nat Rev Clin Oncol. 2016; 13:143-58. [PubMed: 26598942]

$54 * *$. Khalil DN, Smith EL, Brentjens RJ, Wolchok JD. The future of cancer treatment: immunomodulation, CARs and combination immunotherapy. Nat Rev Clin Oncol. 2016; 13:394. Brief review of the future of immunotherapeutics. [PubMed: 27118494]

55. Kim JM, Chen DS. Immune escape to PD-L1/PD-1 blockade: seven steps to success (or failure). Ann Oncol. 2016; 27:1492-504. [PubMed: 27207108]

56. Hellmann MD, Rizvi NA, Goldman JW, Gettinger SN, Borghaei H, Brahmer JR, Ready NE, Gerber DE, Chow LQ, Juergens RA, Shepherd FA, Laurie SA, Geese WJ, Agrawal S, Young TC, Li X, Antonia SJ. Nivolumab plus ipilimumab as first-line treatment for advanced non-small-cell lung cancer (CheckMate 012): results of an open-label, phase 1, multicohort study. Lancet Oncol. 2017; 18:31-41. [PubMed: 27932067]

57. Weber JS, Postow M, Lao CD, Schadendorf D. Management of Adverse Events Following Treatment With Anti-Programmed Death-1 Agents. Oncologist. 2016; 21:1230-40. [PubMed: 27401894]

58. Horvat TZ, Adel NG, Dang TO, Momtaz P, Postow MA, Callahan MK, Carvajal RD, Dickson MA, D’Angelo SP, Woo KM, Panageas KS, Wolchok JD, Chapman PB. Immune-Related Adverse Events, Need for Systemic Immunosuppression, and Effects on Survival and Time to Treatment Failure in Patients With Melanoma Treated With Ipilimumab at Memorial Sloan Kettering Cancer Center. J Clin Oncol. 2015; 33:3193-8. [PubMed: 26282644]

59. Ryder M, Callahan M, Postow MA, Wolchok J, Fagin JA. Endocrine-related adverse events following ipilimumab in patients with advanced melanoma: a comprehensive retrospective review from a single institution. Endocr Relat Cancer. 2014; 21:371-81. [PubMed: 24610577]

60**. Naidoo J, Wang X, Woo KM, Iyriboz T, Halpenny D, Cunningham J, Chaft JE, Segal NH, Callahan MK, Lesokhin AM, Rosenberg J, Voss MH, Rudin CM, Rizvi H, Hou X, Rodriguez K, 
Albano M, Gordon RA, Leduc C, Rekhtman N, Harris B, Menzies AM, Guminski AD, Carlino MS, Kong BY, Wolchok JD, Postow MA, Long GV, Hellmann MD. Pneumonitis in Patients Treated With Anti-Programmed Death-1/Programmed Death Ligand 1 Therapy. J Clin Oncol. 2017; 35:709-17. Epub 2016/09/21. Description of clinical, radiologic, and pathologic features of immune-related pneumonitis. [PubMed: 27646942]

61. Borghaei H, Paz-Ares L, Horn L, Spigel DR, Steins M, Ready NE, Chow LQ, Vokes EE, Felip E, Holgado E, Barlesi F, Kohlhaufl M, Arrieta O, Burgio MA, Fayette J, Lena H, Poddubskaya E, Gerber DE, Gettinger SN, Rudin CM, Rizvi N, Crino L, Blumenschein GR Jr, Antonia SJ, Dorange C, Harbison CT, Graf Finckenstein F, Brahmer JR. Nivolumab versus Docetaxel in Advanced Nonsquamous Non-Small-Cell Lung Cancer. N Engl J Med. 2015; 373:1627-39. [PubMed: 26412456]

62. Brahmer J, Reckamp KL, Baas P, Crino L, Eberhardt WE, Poddubskaya E, Antonia S, Pluzanski A, Vokes EE, Holgado E, Waterhouse D, Ready N, Gainor J, Aren Frontera O, Havel L, Steins M, Garassino MC, Aerts JG, Domine M, Paz-Ares L, Reck M, Baudelet C, Harbison CT, Lestini B, Spigel DR. Nivolumab versus Docetaxel in Advanced Squamous-Cell Non-Small-Cell Lung Cancer. N Engl J Med. 2015; 373:123-35. [PubMed: 26028407]

63. Herbst RS, Baas P, Kim DW, Felip E, Perez-Gracia JL, Han JY, Molina J, Kim JH, Arvis CD, Ahn MJ, Majem M, Fidler MJ, de Castro G Jr, Garrido M, Lubiniecki GM, Shentu Y, Im E, DolledFilhart M, Garon EB. Pembrolizumab versus docetaxel for previously treated, PD-L1-positive, advanced non-small-cell lung cancer (KEYNOTE-010): a randomised controlled trial. Lancet. 2016; 387:1540-50. [PubMed: 26712084]

64. Reck M, Rodriguez-Abreu D, Robinson AG, Hui R, Csoszi T, Fulop A, Gottfried M, Peled N, Tafreshi A, Cuffe S, O'Brien M, Rao S, Hotta K, Leiby MA, Lubiniecki GM, Shentu Y, Rangwala R, Brahmer JR, Investigators K. Pembrolizumab versus Chemotherapy for PD-L1-Positive NonSmall-Cell Lung Cancer. N Engl J Med. 2016; 375:1823-33. [PubMed: 27718847] 

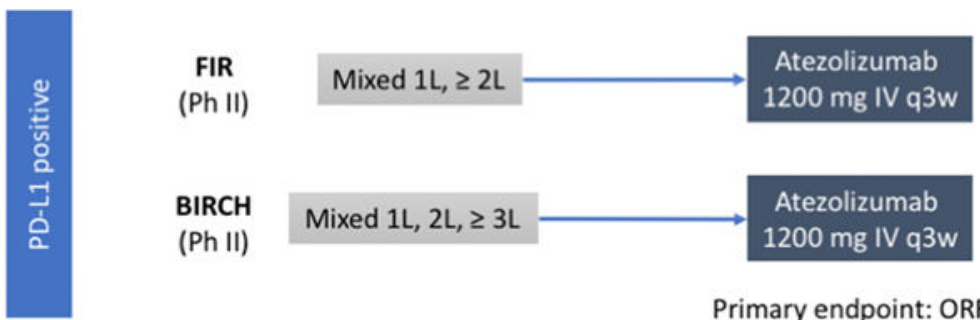

\section{BIRCH}

(Ph II)

Mixed $1 \mathrm{~L}, 2 \mathrm{~L}, \geq 3 \mathrm{~L}$

Atezolizumab

$1200 \mathrm{mg}$ IV q3w

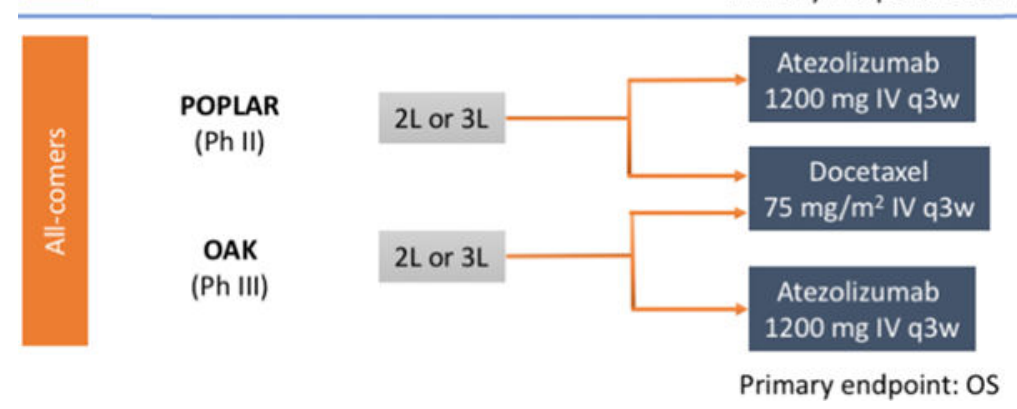

Figure 1.

Atezolizumab phase 2 and phase 3 studies outline 


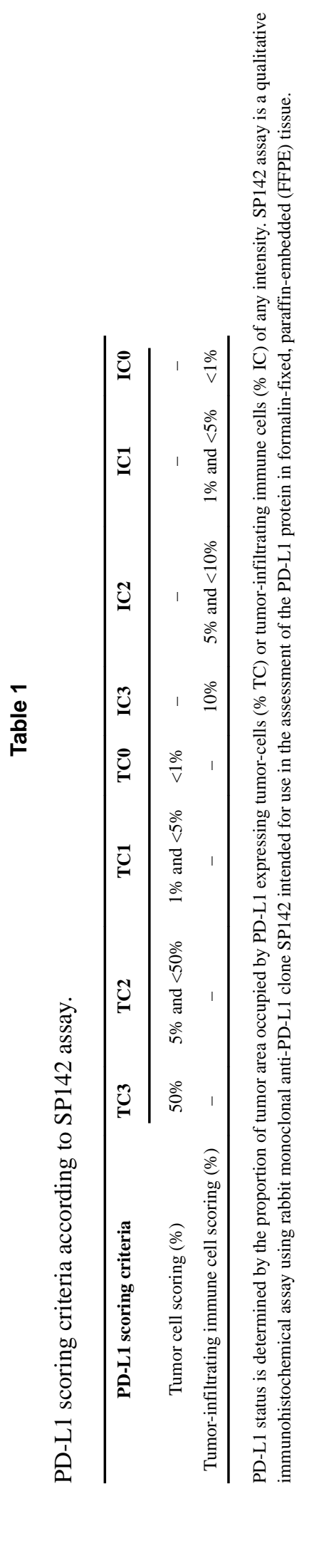




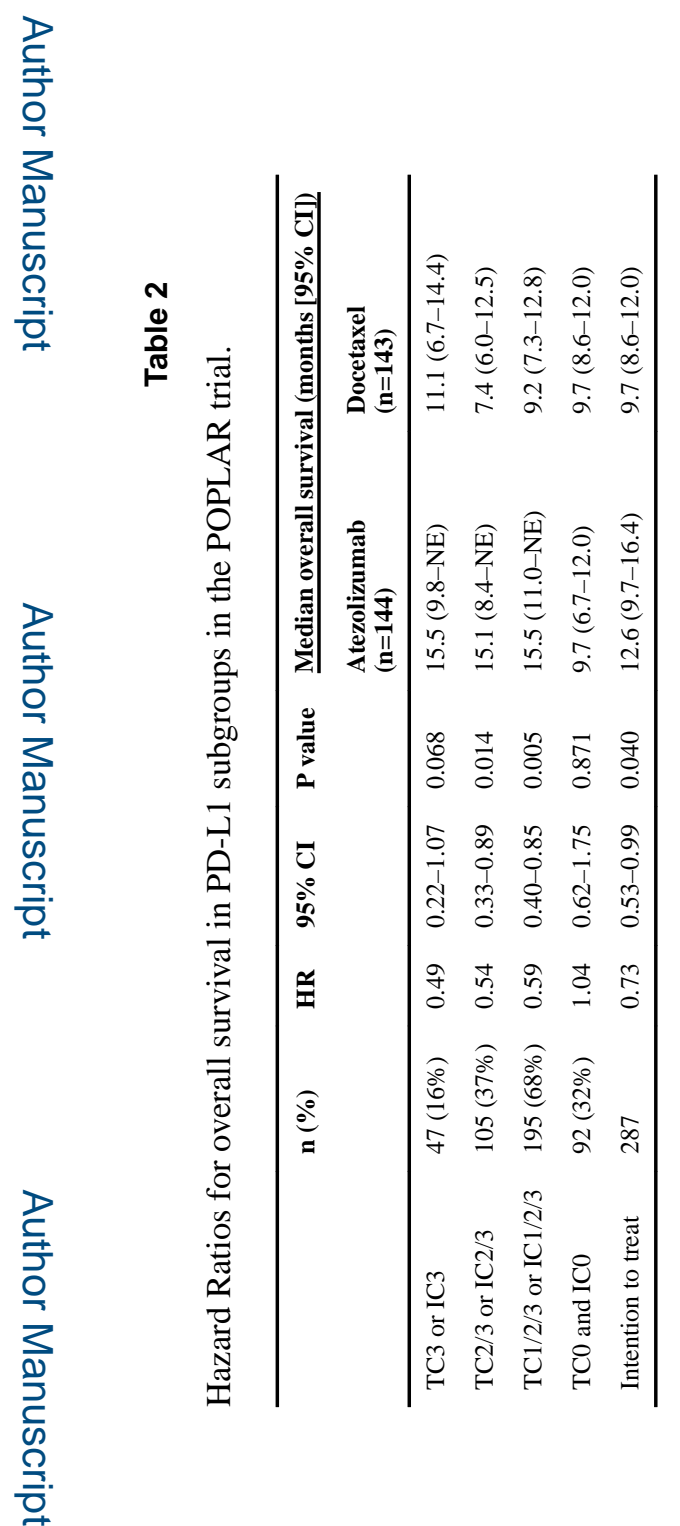

Expert Rev Clin Pharmacol. Author manuscript; available in PMC 2018 August 13. 
Table 3

"BIRCH" efficacy data according to PD-L1 expression - cohort 1

\begin{tabular}{lll}
\hline & TC3 or IC3 (High) & TC 2/3 or IC2/3 (Medium and High) \\
\cline { 2 - 3 } Median OS, months (95\% CI) & NE (12.0-NE) & $20.1(20.1-\mathrm{NE})$ \\
Median PFS, months (95\% CI) & $5.6(2.7-8.3)$ & $5.4(3.0-6.9)$ \\
ORR (95\% CI) & $31 \%(20-43)$ & $30 \%(15-29)$ \\
\hline
\end{tabular}

TC3 or IC3 (High) TC 2/3 or IC2/3 (Medium and High)

$5.6(2.7-8.3) \quad 5.4(3.0-6.9)$ 
Table 5

PD-L1 scoring criteria, prevalence and overlap between PD-L1 expression on TCs and tumor-infiltrating ICs.

\begin{tabular}{lllll}
\hline Overall prevalence & & & \multicolumn{2}{l}{ Prevalence in overlapping subgroups } \\
\hline Subgroup & POPLAR & OAK & Subgroups & POPLAR \\
\hline TC3 or IC3 & $16 \%$ & $16 \%$ & TC3 and IC3 & $<1 \%$ \\
\hline TC2/3 or IC $2 / 3$ & $37 \%$ & $31 \%$ & TC2/3 and IC $2 / 3$ & $7 \%$ \\
\hline TC1/2/3 or IC $1 / 2 / 3$ & $68 \%$ & $54 \%$ & TC1/2/3 and IC $1 / 2 / 3$ & $26 \%$ \\
\hline TC0 and IC0 & $32 \%$ & $45 \%$ & TC0 and IC 0 & $32 \%$ \\
\hline
\end{tabular}




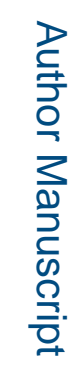

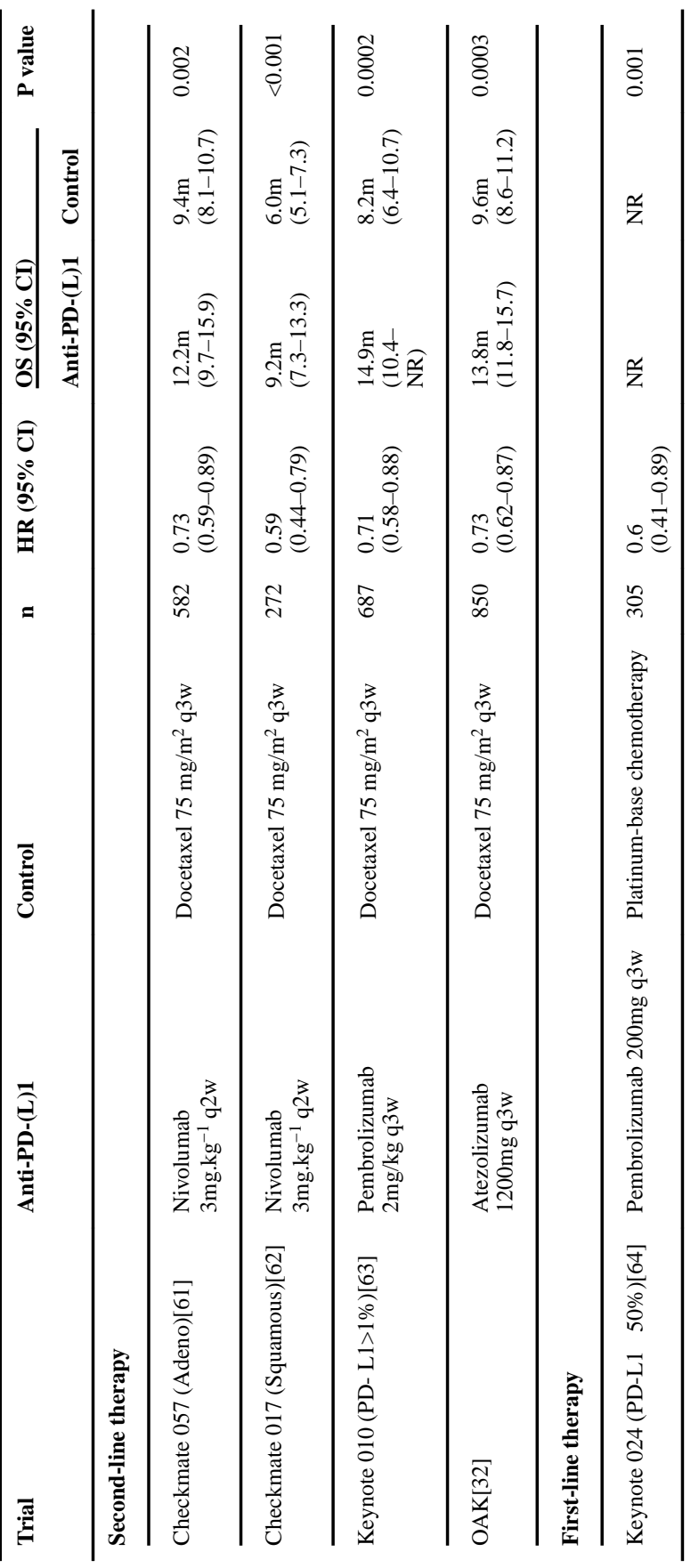

Expert Rev Clin Pharmacol. Author manuscript; available in PMC 2018 August 13. 


\section{Table 7}

Atezolizumab ongoing clinical trials

\begin{tabular}{|c|c|c|c|}
\hline Clinical trial & Phase & Treatment arms & Inclusion criteria \\
\hline NCT02013219 & $1 \mathrm{~b}$ & Atezo + Erlotinib or Alectinib & $E G F R$-mutant or $A L K$-positive Stage IV NSCLC \\
\hline NCT02486718 & 3 & Atezolizumab vs BSC & $\begin{array}{l}\text { Stage IB-IIIA NSCLC after surgery and adjuvant } \\
\text { chemotherapy }\end{array}$ \\
\hline NCT02409342 & 3 & Atezo vs chemotherapy & Stage IV NSCLC PD-L1 positive (1L) \\
\hline NCT02367794 & 3 & Atezo + chemo vs chemotherapy & Stage IV Squamous cell carcinoma (1L) \\
\hline NCT02657434 & 3 & Atezo + chemo vs chemotherapy & Stage IV Adenocarcinoma (1L) \\
\hline NCT02927301 2 & & $\begin{array}{l}\text { Neoadjuvant }+ \text { Adjuvant } \\
\text { Atezolizumab }\end{array}$ & Stage IB-IIIA NSCLC \\
\hline NCT02599454 & 1 & Atezolizumab + SBRT & Inoperable Stage I NSCLC \\
\hline NCT02655822 1/1b & & $\begin{array}{l}\text { Atezo + CPI-444 (adenosine-A2A receptor } \\
\text { inhibitor) }\end{array}$ & Selected Incurable Cancers \\
\hline NCT02495636 & 2 & Atezo + CDX-1401 & Stage IIIB/IV recurrent NSCLC \\
\hline
\end{tabular}

Abbreviations: SBRT: Stereotactic Ablative Radiotherapy; Chemo: chemotherapy; BSC: best supportive care; Atezo: atezolizumab 